\title{
Prognostic Competence and Coping Strategies of International Students from India and Arab Countries
}

\section{Vera Fedotova ( $\nabla$ vera_goldyreva@mail.ru )}

National Research University Higher School of Economics

\section{Research Article}

Keywords: culture, coping strategies, anticipatory competence, socio-cultural adaptation, adaptation scales

Posted Date: January 20th, 2021

DOI: https://doi.org/10.21203/rs.3.rs-135970/v1

License: (ㅇ (i) This work is licensed under a Creative Commons Attribution 4.0 International License. Read Full License 


\section{Abstract}

Background. In the twenty-first century, many universities have internationalized their activity. The number of international students is one indicator of how successful an institution is in the world market of educational services. There is a number of works dedicated to adaptation of international students. However, the anticipatory competence of foreign students and coping strategies in the process of adaptation in a foreign cultural environment have not been previously studied.

Methods. Coping strategies were assessed by using the "Coping Strategies for Stress Situations Test» (Strategic Approach to Coping Scale - SACS) (Vodopyanova \& Starchenkova, 2009); the anticipatory competence of foreign students was assessed by using the anticipatory competence test (Mendelevich, 2003). The study involved young people studying in Russian universities from 1 year to 3 years in humanitarian and technical specialties

Results. During the study it was found that students from Arab countries are dominated by a passive coping strategy, they are in a small degree characterized by asocial and aggressive actions, which are expressed in an asocial strategy of coping with stress. Indian students prefer a pro-social strategy of behavior, expressed in the search for social support. Significant differences were revealed between representatives of two different countries in the severity of the strategy of coping with stress - the search for social support. Personal-situational and temporal anticipatory consistency is more characteristic of students from Arab countries.

Conclusion. The results of the present research work contribute to the knowledge on the ability to predict problematic situations (anticipatory competence) that international students have, in relation to their affiliation. The practical significance of the present research consists in the potential application of the obtained results. Methodical techniques developed in the course of the present research may be applied by specialists in a psychological service when they work with international students.

\section{Introduction}

In the twenty-first century, many universities have internationalized their activity. The number of international students is one indicator of how successful an institution is in the world market of educational services. The international character of modern education is evident in the increase of academic mobility and the growth of numbers of international students. Most often, people adapt to a new socio-cultural environment by changing their stereotypes and behavioral patterns; however, they often remain internally alienated from the social environment. Successful adaptation ensures faster integration into the learning process and an overall increase in quality of education for international students.

To date, problems related to sociocultural adaptation have been studied in scientific works by A.C. Mui, S. Kang, 2006; R. An, S.Y. Chang, 2015; J. Wang, J. Hong, Z. Pi, 2015; S. Potochnick, 2018; M. Zhang, M. Rask, 2019; R. Peng, W. Wu, 2019, and others. 
There are a number of works dedicated to the adaptation of international students (Zhou, Topping \& Jindal-Snape, 2011; Merenkov \& Antonova, 2015; Pham \& Lim, 2016; Glass, Gomez \& Urzua, 2014; Hunley, 2010; Wang, et al., 2015; Szabo et al., 2016; Hirai et al., 2015; Poyrazli \& Lopez, 2007; Constatntine et al., 2005; Crockett et al., 2007; Karrupan \& Barari, 2011; Gertzog et al., 2017 and others). However, in the listed works, anticipation competence and coping strategies of foreign students in the process of adapting to foreign cultural environments have not been previously studied. It should be noted that much research in the field of psychology is dedicated to anticipation and prediction, under various aspects: from the point of view of general psychology, medicine, psychology and pedagogy, and ontogenetically (Grigoryeva, 2015; Petrova \& Leontyeva, 2017; Natalova \& Chylova, 2011; Merc \& Subasi, 2015 and others). This article will define the anticipatory competence of international students studying in Russia. Anticipation is the ability of a subject to act and decide with a certain space-time prediction of expected future events. The notions of "anticipation" and "anticipatory capacities" have the same meaning, which makes these categories identical in most psychological contexts (Nichiporenko \& Mendelevich, 2006). Anticipatory or prognostic competence is the ability to expect the development of events with high probability, to predict how situations will develop and how an individual will react to them, and to be a few steps ahead when taking action (Mendelevich \& Solovyeva, 2002, p. 99). At the present time, there are no studies that explore the anticipatory competence of international students.

\section{Adaptation}

In the current era of globalization, there are an increasing number of students seeking higher education outside their native culture (Rienties \& Tempelaar, 2013). Educational experiences in host cultures provide an opportunity to expand an individual's intercultural knowledge and worldview, which in turn enhances personal development and future career prospects (Rienties et al., 2013). However, the process of adapting to a new culture can be difficult and stressful (Berry, 2005; Ward et al., 2001).

Sociocultural adaptation is defined as the ability to understand the culture of the host country and function properly in a new cultural environment (Kim, 1988, 2001; Ward, 2001). During socio-cultural adaptation, the individual experiences cultural stress (Berry \& Annis, 1974), which can be alleviated by social support (Adelman, 1988). Researchers argue that an additional aspect of cross-cultural adaptation that needs to be studied is psychological adaptation, though they highlight the close relationship between cultural stress and human mental health. People with high levels of acculturative stress are at risk of experiencing not only depression (Mui \& Kang, 2006; Rahman \& Rollrock, 2004), but also suicidal ideation (Hovey \& King, 1996). Further research has shown that acculturative stress is correlated with high levels of anxiety and depression in international students (Crockett et al., 2007). As scientists note, international students in the process of adapting to a foreign cultural environment experience a sense of loneliness (Hunley, 2010; Wang, et al., 2015), face difficulties caused by changes to their usual way of life (Szabo et al., 2016), experience cultural differences (Hirai et al., 2015), and discrimination (Poyrazli \& Lopez, 2007; Ward \& Leung, 2005). 
In the context of the adaptation of international students to the new environment of a Russian university, as well as defining the structure of adaptation, the issue of coping strategies used to overcome difficulties is of particular relevance.

\section{Coping behavior strategies}

International students come to study in Russia from around the world. They are representatives of different cultures and traditions, values and norms of behavior. Despite some experience already gained in their native country, education and lifestyle in Russia are very different for international students. In addition, each student has a different level of proficiency in Russian, special individual psychological qualities and specific ways of coping with stress.

Recent studies have explored differences in coping strategies and ranking of life values among students of different ethnic groups. The sample of one study comprised 441 international students in Russian universities: Africans - 149, Turkish people - 164, Mongols - 128 (Darinskaia et al., 2017). This study concluded that psychological support should facilitate formation of sociocultural competence and development of coping strategies connected with social contacts and rationalization. In group training sessions it is necessary to focus on universal values and prevention of behavioral abnormalities.

The aim of another study, held in Russia, was to determine the safe and unsafe types of defensive and coping behavior of students. The study involved 332 college and university students from the first to the fourth years of study (from 16 to 22 years old) from Ekaterinburg (Nikiforova, 2016). The author identified four types of defensive and coping behavior: adaptive, victim, neurotic, and altruistic. Many protective and coping behaviors were divided into two types: safe or unsafe, directed at oneself or at others. "Adaptive" and "altruistic" types of behavior are attributed to safe defensive and coping behavior, and "neurotic" and "victim" types are attributed to unsafe behavior.

Several studies conducted outside of Russia have also examined students' coping strategies. One of those studies looked at the coping strategies used by the students of the Faculty of Economy and Management at the Czech University, within the "Governmental management and regional development" study programme $(n=177)$. The research showed age differences between students, and differences between the groups of part-time and full-time students, regarding the following coping strategies: situational control, reaction control, positive self-teaching. Such coping strategies were dominant among part time-students of the Faculty of Economy and Management at the Czech University (Natovova \& Chylova, 2012).

Another study involved Turkish students as respondents: 12 EFL students who had finished their study practice at the Anadolu University. Participants were asked to keep a diary where they had to describe their adaptation issues. The research data also included semi-structured interviews and field notes taken by researchers. The analysis of the data showed that the most serious adaptation problems were related 
to interpersonal communication inside a group, and the most successful coping strategy was when cooperation occurred between students and teachers with a similar mindset (Merc \& Subası, 2015).

Research by Australian authors (Khawaja et al., 2001) used a quantitative approach to investigate problems that international students may encounter. Twenty-two international students from a university in Australia took part in four focus groups. It was found that the students' problems included their social isolation, their limited English skills, academic struggles, expectations that weren't satisfied, a tight schedule, cultural shock and psychological discomfort. The main coping strategies implemented by the international students involved seeking additional information, leaving their comfort zone, interacting actively with native speakers in the hosting country, practicing their social skills, developing time management skills, and approaching the university for psychological counselling.

The results of another study showed that, in stressful situations, international students used different coping strategies when compared to domestic students (Sapranaviciute, 2012). The study recruited 356 students: 258 host and 98 international students. The coping strategies used by international and domestic students were different related to their health outcomes.

A series of studies has been based on the responses of Chinese students (Cao, C., et al., 2017; Cao, C., et al., 2018). Consensual qualitative research (CQR) was used to analyze data gathered from semistructured interviews. Chinese students in various universities around the world were recruited. The authors defined several academic stressors and differentiated them according to frequency labels. The dominant sources of academic stress were: academic incompetence, cultural shock, different academic standards, and intercultural communication issues. It was found that Chinese students had been getting social support in the academic context from their compatriots of the same age. The results implied that their culture mainly influenced the behavioral peculiarities of Chinese students and not the general academic context. Indian students have also been recruited as respondents in studies dedicated to revealing the problems of adaptation to Russian universities (Shkuhov \& Radchenko, 2011; Abramova et al., 2018). Authors have found that it is possible to make the adaptation process easier and faster by supporting the education and residence of students from different countries with a consideration for their historical and cultural heritage, and the national and religious characteristics of the individuals involved in the educational space (Abramova et al., 2018).

Although several studies have examined coping strategies used by international students, it should be pointed out that most studies do not differentiate students by their nationality. Existing studies do not provide any analysis of the differences between coping strategies used by the representatives of different cultures.

Therefore, in the existing literature, one can see contradictions between the amount of empirical data on adaptation of international students and the lack of research aimed at revealing coping strategies and how international students can predict problematic situations and overcome them. 


\section{Present study}

The aim of this research is to study the characteristics of the socio-cultural adaptation of international students. The objectives of this study are:

1. To study the anticipatory competence of international students associated with adaptation.

2. To study the coping strategies of international students to the new conditions of the educational environment of the university.

The scientific novelty of the presented work is to identify coping strategies and components of the anticipatory competence of students from China and students from the CIS countries studying in Russia. The anticipatory competence of international students has not previously been studied, especially in the cross-cultural aspect.

\section{Methods}

\section{Participants}

The present research is based on data obtained from first-, second- and third-year students from India (73 respondents) and Arabic countries (64 respondents). The informants are currently studying in institutions of higher education in Perm, Moscow, Astrakhan, Kazan, Nizhny Novgorod, St. Petersburg.

The first group of informants was composed of students from Arabic countries (Morocco, Syria), of an average age of 23 (33 male and 29 female respondents).

The second group included 73 Indian students (39 males and 24 females) who had been studying at Russian institutions of higher education for 1 to 3 years, specialized in humanities and technical science. The average age of informants was 23 . The overall number of respondents equals to 137 (see Table 1).

Table 1

Socio-demographic characteristics of the study sample

\begin{tabular}{|lll|}
\hline Respondents & Number of respondents & Age \\
\hline Arabic-speaking students & 64 & Min: 19 \\
& & Max: 25 \\
& & Average: 22 \\
\hline Indian students & 73 & Min: 18 \\
& & Max: 25 \\
& & Average: 23 \\
\hline
\end{tabular}




\section{Procedure}

During the study, we used two techniques. A questionnaire was presented to the respondents in two ways: face-to-face and online using Google Forms. First, we identified the dominant coping strategies for people from unique cultures using "Coping Strategies for Stress Situations», calculating the average for each strategy. We also calculated the standard deviation for each of the variables and differences between groups. Secondly, we analyzed the data using the method "Anticipatory competence test", revealing the indicators of anticipatory consistency using descriptive statistics. The study involved young people studying in Russian universities from 1 year to 3 years in humanitarian and technical specialties. Students from Moscow, Astrakhan, Kazan, Nizhny Novgorod, and St. Petersburg filled out an online questionnaire which was distributed through the departments that work with international students. We also distributed the questionnaire on social network groups for international students. International students from Perm city filled out a questionnaire in the presence of an interviewer. Nevertheless, we should acknowledge the potential cognitive biases commonly associated with self-reported measures, such as the effect of social desirability. The respondents were unfamiliar with each other, and the purpose of the study was not indicated in the questionnaire itself.

\section{Measures}

\section{Coping strategies}

This was assessed by using the test Coping Strategies for Stress Situations (Strategic Approach to Coping Scale - SACS) (Vodopyanova \& Starchenkova, 2009). This method uses a questionnaire of 54 statements. Using the assessment key, a grade is calculated for each of the following scales: "assertive actions», "starting social contact», "seeking social support», "cautious actions», «impulsive actions», «avoidance», «indirect actions», "asocial actions», and «aggressive actions». According to the theory suggested by Hobfoll, the models of coping are characterized by three axes of an individual's behavior. The strategic direction of coping behavior can be described by three coordinates: the pro-social/asocial strategy axis, the passive/active axis, and the direct/indirect (manipulative) action axis (Vodopyanova \& Starchenkova, 2009).

\section{Anticipatory competence}

This was assessed by the anticipatory competence test (Mendelevich, 2003). V.D. Mendelevich and G.D. Khafizova tested and approved the method in 2007. They researched the connection between anticipatory competence and volitional activities in patients with personality disorders (Mendelevich \& Khafizova, 2007). Although the method «Anticipatory competence test» was originally used to identify personality disorders, according to the developers, the concept can be used outside of clinical psychology (Mendelevich, Nechiporenko, 2010). Anticipatory solvency is becoming a subject for study in other areas, 
including education (Danilenko, 2018). The possibility of a wide range of applications of this technique allowed us to use it in the presented study, since the treatment of time and the features of communication can be because of cultural differences (Lewis, 2016).

\section{Analysis of rhe data}

The primary analysis of the answers given by the respondents has enabled us to calculate the minimum, maximum and mean values, standard deviation for each variable, and differences revealed using Student's t-distribution. Differences in the features of anticipatory competence were identified using analysis of variance.

\section{Results}

\section{Revealing coping strategies of international students}

Let us turn to the results obtained in the first block of the questionnaire and reflecting the coping strategies of the respondents. The primary analysis of the respondents' answers made it possible to reveal the mean value and standard deviation for each variable (see Table 2). 
Table 2

Indicators of coping strategies among representatives of India and Arab countries

\begin{tabular}{|c|c|c|c|c|c|c|c|}
\hline \multirow[t]{2}{*}{$\begin{array}{l}\text { Coping } \\
\text { strategies }\end{array}$} & \multirow[t]{2}{*}{$\begin{array}{l}\text { The models } \\
\text { of coping }\end{array}$} & \multicolumn{2}{|c|}{$\begin{array}{l}\text { Students from Arab } \\
\text { countries }\end{array}$} & \multicolumn{2}{|c|}{ Students from India } & \multirow[t]{2}{*}{ p-level } & \multirow{2}{*}{$\begin{array}{l}\text { Effect } \\
\text { size } \\
\text { (Cohen's } \\
\text { d) }\end{array}$} \\
\hline & & $\begin{array}{l}\text { The severity } \\
\text { of the } \\
\text { overcoming } \\
\text { models }\end{array}$ & $\begin{array}{l}\text { St. } \\
\text { dev }\end{array}$ & $\begin{array}{l}\text { The severity } \\
\text { of the } \\
\text { overcoming } \\
\text { models }\end{array}$ & $\begin{array}{l}\text { St. } \\
\text { dev }\end{array}$ & & \\
\hline Active & $\begin{array}{l}\text { Assertive } \\
\text { actions }\end{array}$ & 15 & 0,34 & 16,8 & 0,33 & Insignificant & 0,05 \\
\hline \multirow[t]{2}{*}{$\begin{array}{l}\text { The } \\
\text { prosocial } \\
\text { strategy }\end{array}$} & $\begin{array}{l}\text { Need to } \\
\text { feel } \\
\text { emotional } \\
\text { support }\end{array}$ & 19,7 & 0,81 & 15,3 & 0,59 & Insignificant & 0,07 \\
\hline & $\begin{array}{l}\text { Seeking } \\
\text { social } \\
\text { support }\end{array}$ & $16,3^{\star *}$ & 0,66 & 21,8 ** & 0,48 & $P<0,01$ & 0,95 \\
\hline $\begin{array}{l}\text { The } \\
\text { passive } \\
\text { strategy }\end{array}$ & $\begin{array}{l}\text { Cautious } \\
\text { behaviour }\end{array}$ & 20 & 0,34 & 19,4 & 0,83 & Insignificant & 2,74 \\
\hline $\begin{array}{l}\text { Direct } \\
\text { strategy }\end{array}$ & $\begin{array}{l}\text { Impulsive } \\
\text { actions }\end{array}$ & 15,7 & 0,62 & 15 & 0,55 & Insignificant & 0,01 \\
\hline $\begin{array}{l}\text { The } \\
\text { passive } \\
\text { strategy }\end{array}$ & Avoidance & 19 & 0,64 & 18 & 0,58 & Insignificant & 0,01 \\
\hline $\begin{array}{l}\text { Indirect } \\
\text { strategy }\end{array}$ & $\begin{array}{l}\text { Indirect } \\
\text { actions }\end{array}$ & 15,7 & 0,76 & 16,6 & 0,56 & Insignificant & 0,13 \\
\hline \multirow[t]{2}{*}{$\begin{array}{l}\text { Asocial } \\
\text { strategy }\end{array}$} & $\begin{array}{l}\text { Asocial } \\
\text { actions }\end{array}$ & 14,3 & 0,41 & 13 & 0,54 & Insignificant & 0,02 \\
\hline & $\begin{array}{l}\text { Aggressive } \\
\text { actions }\end{array}$ & 14,3 & 0,59 & 13,8 & 0,61 & Insignificant & 0,08 \\
\hline
\end{tabular}

Students from Arab countries are dominated by a passive coping strategy and, accordingly, such behaviors as cautious actions and avoidance. At the same time, Arab students are in a small degree characterized by asocial and aggressive actions, which are expressed in asocial strategies for coping with stress. Indians prefer a pro-social strategy of behavior, expressed in the search for social support. The strategies of coping with stress that were significant in their expression were identified - the search for social support. 


\section{Revealing anticipatory competence of international students}

Let's move on to the analysis of the results from the second block of the questionnaire aimed at studying anticipatory competence. The primary analysis of the respondents' answers made it possible to reveal the minimum, maximum and mean values, standard deviation for each variable, as well as differences according to the Student's t-test (see Table 3).

Table 3

Indicators of anticipatory competence

\begin{tabular}{|c|c|c|c|c|}
\hline \multirow[t]{2}{*}{ Indicators of anticipatory competence } & \multicolumn{2}{|c|}{$\begin{array}{l}\text { Students from Arab } \\
\text { countries }\end{array}$} & \multicolumn{2}{|c|}{$\begin{array}{l}\text { Students from } \\
\text { India }\end{array}$} \\
\hline & Median & St.dev. & Median & St.dev \\
\hline $\begin{array}{l}\text { Personal and situational anticipatory } \\
\text { competence }\end{array}$ & $194 * *$ & 0,68 & $172,41^{\star *}$ & 0,73 \\
\hline Spatial anticipatory competence & 58,4 & 0,41 & 60,8 & 0,59 \\
\hline Temporal anticipatory competence & $40,2^{*}$ & 0,75 & $37,19 *$ & 0,74 \\
\hline Common anticipatory competence & 292,6 & 0,61 & 270,4 & 0,70 \\
\hline
\end{tabular}

There are significant differences in the components of anticipatory competence among Arab students and Indians studying in Russia. The personal-situational and temporal components of prognostic validity are more pronounced in Arabs. The polyactivity of the Arab and Indian cultures formed the basis for the temporary inconsistency of the representatives of both groups, since the values obtained are below the threshold (less than 42).

\section{Differences in the anticipatory consistency}

During the interpretation of the results, differences in adaptation among Arab students were found depending on the course of study and gender. Differences were found in temporal anticipatory competence among students from Arab countries enrolled in $1(N=15), 2(N=34), 3(N=15)$ courses of Russian universities (see Table 4). 
Table 4

Differences in the temporal anticipatory competence depending on course of the study among Arab students (results of the analysis of variance)

\begin{tabular}{|lllllll|}
\hline & & $\begin{array}{l}\text { Sum of } \\
\text { squares }\end{array}$ & St.sv & $\begin{array}{l}\text { Medium } \\
\text { square }\end{array}$ & F & $p$ \\
\hline $\begin{array}{l}\text { Temporal anticipatory } \\
\text { competence }\end{array}$ & $\begin{array}{l}\text { Between } \\
\text { groups }\end{array}$ & 3,196 & 2 & 1,598 & 3,284 & 0,04 \\
\hline $\begin{array}{l}\text { Within the } \\
\text { group }\end{array}$ & 29,685 & 61 & 0,487 & \\
\hline General & 32,881 & 63 & & \\
\hline
\end{tabular}

It was found that first-year Arab students have the lowest level of temporal anticipatory competence $(\mathrm{M}=$ $31.2, \mathrm{SD}=0.55)$, and second-year students are more able than third-year students to predict difficult situations associated with time $(F=3.284$ at $p=0.04)$.

The revealed differences in adaptation among Arab students depending on gender (29 female students, 33 male students took part in the study) are presented in Table 5.

Table 5

Differences in the spatial anticipatory competence depending on gender among Arab students (results of the analysis of variance)

\begin{tabular}{|lllllll|}
\hline & & $\begin{array}{l}\text { Sum of } \\
\text { squares }\end{array}$ & St.sv & $\begin{array}{l}\text { Medium } \\
\text { square }\end{array}$ & F & $p$ \\
\hline $\begin{array}{l}\text { Spatial anticipatory } \\
\text { competence }\end{array}$ & $\begin{array}{l}\text { Between } \\
\text { groups }\end{array}$ & 2,433 & 1 & 2,443 & 4,964 & 0,03 \\
$\begin{array}{l}\text { Within the } \\
\text { group }\end{array}$ & 29,526 & 60 & 0,492 & & \\
\hline General & 31,969 & 61 & & \\
\hline
\end{tabular}

It was found that the level of spatial anticipatory competence is higher among female Arab students ( $\mathrm{M}=$ $61.2 \mathrm{SD}=0.59)$. The data obtained contradict the previously established facts about the severity of spatial intelligence in men compared to women (Kaufman, 2007; Parsons et al., 2004; Syzmanowicz \& Furnham, 2011).

It is necessary to mention that no differences were found in coping strategies in relation to gender and course among Arab students. Indians show no differences in coping strategies and anticipatory competence depending on the course and gender.

\section{Discussion}


It is common for respondents from Arab countries to postpone solving a problem in the hope that it will resolve itself; save energy and prefer to do anything, just to forget about the unpleasant business that needs to be done. Hindus consult with friends and relatives, do not hesitate to turn to other people for help and support, and in difficult times emotional support of loved ones is extremely important for them.

Significant differences were revealed in the severity of the strategy for coping with stress - the search for social support. Hindus do not try to hide their feelings - they express joy, disappointment and grief openly. Their values are centered on family as well as group dedication. Group membership is dominant in Indian culture. Ingroups are of great importance.

Also, Arabs are able to predict situations related to communication, to a greater extent than Indians. Previously, nothing was known in science about the anticipatory consistency of foreign students, but the low temporary AS of Indians and Arabs (the value of the temporal AS is below the threshold value - less than 42) is culturally determined. Representatives of Arab countries are sociable, mobile, do a lot of things at once and not according to the schedule, but according to the degree of their attractiveness, importance at a given time, and the carriers of this type of culture are extroverted, impatient, talkative. They are often unpunctual, have a habit of being late, do not schedule time and do not keep records of their affairs. All these characteristics are reflected in the temporal anticipatory consistency of foreign students from India and Arab countries.

The obtained data, namely the peculiarities of coping strategies and the ability to predict situations related to communication, predicting the flow of time and the ability to distribute it, can form the basis for the development of accompanying adaptation programs for students belonging to different cultures. Not only adaptation programs, but also the training system for foreign students should take into account the differences between the carriers of a particular culture. When developing adaptation programs for foreign students studying in Russia, it should be borne in mind that Arab students, as representatives of a polychronous, polyactive and highly contextual culture, are easier to adapt to the educational process directly through communication. They allocate time a little more efficiently, personal-situational anticipatory competence is developed to a greater extent than among the Indians. Hindus are the group of students who need to clearly define deadlines, warn about current controls, and pay special attention to time management themselves, since the temporal anticipatory consistency is less pronounced. The revealed differences in coping strategies demonstrate that Indian students are more eager to seek social support. It is extremely difficult for them to predict difficult situations associated with time and communication, while they have a high need for social support as a coping strategy, respectively, by focusing on this, you can accelerate their adaptation to the educational process. Arab students have more developed personality-situational anticipatory competence than students from India.

Thus, in the course of the study, it was found that:

1. Students from Arab countries are dominated by a passive coping strategy, they are in a small degree characterized by asocial and aggressive actions, which are expressed in an asocial strategy of coping with stress.

Page 12/18 
2. Hindus prefer a pro-social strategy of behavior, expressed in the search for social support.

3. Significant differences were revealed between representatives of two different cultures in the severity of the strategy of coping with stress - the search for social support.

4. Personal-situational and temporal anticipatory consistency is more characteristic of students from Arab countries.

5. It was found that the level of spatial anticipatory consistency is higher among female Arab students.

\section{Conclusions}

Of course, the study of the peculiarities of adaptation of foreign students to the educational space of a Russian university is an urgent topic today. Despite the existence of a number of Russian and foreign studies aimed at studying the adaptation strategies of foreign students, it should be noted that they do not study the issue of coping strategies and anticipatory consistency. The theoretical value of the present research consists in enriching psychological knowledge on the phenomenon of adaptation to the environment of Russian universities experienced by international students. The obtained data will benefit the further development of the studies of coping strategies used by international students. The results of the present research work contribute to the knowledge on the ability to predict problematic situations (anticipatory competence) that international students have, in relation to their affiliation. The practical significance of the present research consists in the potential application of the obtained results. They may be used as study materials in various disciplines: "Psychology of a personality", "Intercultural communication", "Intercultural communication in the modern world". The results of the present research paper may prove useful in the professional activities of a practicing psychotherapist in consulting and preventive work aimed at helping international students adapt to the environment of a Russian university. Methodical techniques developed in the course of the present research may be applied by specialists in a psychological service when they work with international students.

\section{Declarations}

\section{Ethics approval and consent to participate}

The study was approved by an ethics committee of the National Research University Higher School of Economics. All methods were carried out in accordance with the Declaration of Helsinki and its amendments and were approved by the ethics committee of the National Research University Higher School of Economics. Informed consent was obtained from all participants.

\section{Consent for publication}

Not applicable. 


\section{Availability of data and materials}

The dataset supporting the conclusions of this article are available on request (by contacting vera_goldyreva@mail.ru).

\section{Competing interest}

The author declare that she has no competing interests.

\section{Funding}

N/A

\section{Authors' contributions}

The scientific work was written by the author under the guidance of a scientific supervisor at PSU, Perm

\section{Acknowledgements}

I want to thank management of Russian universities and departments working with foreign students for their assistance in participant recruitment and data collection.

\section{Authors' information (optional).}

N/A

\section{References}

1. Abramova, I. E., Ageeva, N. A., Shapovalov G. N., Lysenko K. N., Samofalova M. V. (2018). RussiaIndia: Indian student's adaptation in Russian universities in the context of the dialogue of civilization and cultures. Periodico Tche Quimica, 15(38), 87-94.

2. Adelman, M.B. (1988). Cross-cultural adjustment: A theoretical perspective on social support. International Journal of Intercultural Relations, 12 (3), 183-204.

3. An, R., Chiang, S. Y. (2015). International students' culture learning and cultural adaptation in China. Journal of Multilingual and Multicultural Development, 36, 661-676.

4. Berry, J. W. (2005). Acculturation: Living successfully in two cultures. International Journal of Intercultural Relations, 29, 697-712. 
5. Berry, J.W., Annis, R.C. (1974). Acculturative stress: The role of ecology, culture, and differentiation. Journal of Cross-Cultural Psychology, 5 (4), 382-406. 1177/002202217400500402

6. Cao, C., Men, Q., \& Shang, L. (2018). How can Chinese international students' host-national contact contribute to social connectedness, social support and reduced prejudice in the mainstream society? Testing a moderated mediation model. International Journal of Intercultural Relations, 63, 43-52. doi: 10.1016/j. ijintrel.2017.12.002.

7. Cao, C., Zhu, C., \& Meng, Q. (2017). Predicting Chinese international students' acculturation strategies from socio-demographic variables and social ties. Asian Journal of Social Psychology, 20, 85-96. doi: $1111 /$ ajsp. 12171

8. Constantine, M.G., Anderson, G.M., Berkel, L.A., Caldwell, L.D., \& Utsey, S.O. (2005). Examining the cultural adjustments experiences of African international college students: A qualitative analysis. Journal of Counseling Psychology, 52, 3-13.

9. Crockett, L. J., Iturbide, M. I., Torres Stone, R. A., McGinley, M., Raffaelli, M., \& Carlo, G. (2007). Acculturative stress, social support, and coping: Relations to psychological adjustment among Mexican American college students. Cultural Diversity and Ethnic Minority Psychology, 13, 347- 355.

10. Danilenko, O.I. (2018). Anticipatory consistency as a predictor of the subjective well-being of students // Azimuth of scientific research: pedagogy and psychology, 3 (24), 264-268.

11. Gertsog, G.A., Danilova, V.V., Uvarina, N.V., Savchenkov, A.V., Korneev, D.N. (2017). Professional Identity for Successful Adaptation of Students - a Participative Approach. Rupkatha Journal on Interdisciplinary Studies in Humanities, 1, 301-306. DOI: 10.21659/rupkatha.v9n1.30

12. Glass, C., Gómez, E., Urzua, A. (2014). Recreation, intercultural friendship, and international students' adaptation to college by region of origin.International Journal of Intercultural Relations, 42, pp.104117.

13. Grigoryeva, M.V. (2015). Adaptive mechanisms of the process of sociocultural integration. Sociocultural integration and special education, pp. 37-42.

14. Hirai, R., Frazier, P., Syed, M. (2015). Psychological and sociocultural adjustment of first-year international students: Trajectories and predictors. Journal of Counseling Psychology, 62 (3), 438452. https://doi.org/10.1037/cou0000085.

15. Hovey, J. D., King, C. A. (1996). Acculturative stress, depression, and suicidal ideation among immigrant and second-generation Latino adolescents. Journal of the American Academy of Child and Adolescent Psychiatry, 35, 1183- 1192.

16. Hunley, H. A. (2010). Students' functioning while studying abroad: The impact of psychological distress and loneliness. International Journal of Intercultural Relations, 34 (4), 386-392. https://doi.org/10.1016/j.jijintrel.2009.08.005.

17. Karruppan, C.M., Barari, M. (2011). Perceived discrimination and international students' learning: An empirical investigation. Journal of Higher Education, 33, 67-83.

18. Kaufman, S. B. (2007). Sex differences in mental rotation and spatial visualization ability: Can they be accounted for by differences in working memory capacity. Intelligence, 35(3), 211-223. 
https://doi.org/10.1016/j.intell.2006.07.009

19. Khawaja, N., Stallman, H. (2011). Understanding the coping strategies of international students: A qualitative approach.Australian Journal of Guidance and Counselling, 2, 203-224. doi:10.1375/ajgc.21.2.203.

20. Kim, Y. Y. (1988). Communication and cross-cultural adaptation: An integrative theory, International Journal of Intercultural Relations, 12, 291-293.

21. Kim, Y. Y. (2001). Becoming intercultural: An integrative theory of communication and cross-cultural adaptation. London: Sage.

22. Lewis, R. (2016). When culture collide: leading across cultures. Boston, USA: WS Bookwell Publ.

23. Mendelevich, D., \& Khafizova, G. D. (2007). Vzaimosvyaz' antitsipatsionnoi sostoyatel'nosti i volevoi deyatel'nosti u patsientov s lichnostnymi rasstroistvami [Interrelation between anticipatory solvency and volitional activity in patients with personality disorders]. Prakticheskaja medicina, 3, 52-54.

24. Mendelevich, V. D. (2003). Anticipatory competence test - an experimental psychological technique for assessing readiness for neurotic disorders. Social and Clinical Psychiatry. 13 (1), 35-40.

25. Mendelevich, V. D., Solovyova, S. L. (2002). Neurosology and psychosomatic medicine / V.D. Mendelevich, S.L. Soloviev. M.: MEDpress-inform, 2002.

26. Merc, A., \& Subası, G. (2015). Classroom Management Problems and Coping Strategies of Turkish Student EFL Teachers. Turkish Online Journal of Qualitative Inquiry, 1 (6), 39-71.

27. Merc, A., \& Subası, G. (2015). Classroom management problems and coping strategies of Turkish student EFL Teachers.Turkish Online Journal of Qualitative Inquiry, 1(6), 39-71.

28. Merenkov, A., \& Antonova, N.(2015). Problems of social adaptation of international students in Russia. New Educational Review, 41(3), 122-132. https://doi.org/10.15804/tner.2015.41.3.10

29. Mui, A. C., Kang, S. (2006). Acculturation stress and depression among. Asian immigrant elders. Social Work, 51, 243- 255.

30. Natovova, L., \& Chylova, H. (2012). Coping strategies adopted by university students. Part II: Role con ict and age. Journal on Effciency and Responsibility in Education and Science, 5(4), 226-238. doi: 10.7160/eriesj.2012.050405.

31. Nichiporenko, N. P., \& Mendelevich, V. D. (2006). The phenomenon of anticipatory abilities as a subject of psychological research. Psychological journal, 27(5), 50-59.

32. Nikiforova, D. (2018). The question of defensive and coping student's behavior safety in the educational enviroment. Sibirskiy Psikhologicheskiy zhurnak-Siberian journal of psychology, $62,113-$ 126. doi: $10.17223 / 17267080 / 62 / 9$.

33. Parsons, T., Larson, P., Kratz, K., Thiebaux, M., Bluestein, B., Buckwalter, J. G., Rizzo, A. (2004). Sex differences in mental rotation and spatial rotation in a virtual environment // Neuropsychologia, 42(4), 555-562. https://doi.org/10.1016/j.neuropsychologia.2003.08.014

34. Petrova, S.M., Leontyeva, M.M. (2017).Protection mechanisms and coping strategies of foreign students in the process of their adaptation at the university. Interactive approach to human 
psychology and social interaction of people: Materials of the VII All-Russian scientific-practical conference (St. Petersburg, April 12-14, 2017). St. Petersburg: RGPU im. A.I. Herzen, 333-338.

35. Pham, B., \& Lim, S.S. (2016). Empowering Interactions, Sustaining Ties: Vietnamese Migrant Students' Communication with Left-Behind Families and Friends. In: Lim S. (eds) Mobile Communication and the Family. Mobile Communication in Asia: Local Insights, Global Implications. Springer, Dordrecht. https://doi.org/10.1007/978-94-017-7441-3_7

36. Potochnick, S. (2018). The academic adaptation of immigrant students with interrupted schooling. American Educational Research Journal, 55(4), 859-892.

37. Poyrazli, S., Lopez, M. D. (2007). An exploratory study of perceived discrimination and homesickness: A comparison of international students and American students. The Journal of Psychology, 141(3), 263-280. https://doi.org/10.3200/JRLP.141.3.263-280.

38. Rahman, O., \& Rollock, D. (2004). Acculturation, competence, and mental health among South Asian students in the United States. Journal of Multicultural Counselling and Development, 32,130- 140.

39. Rienties, B., \& Tempelaar, D. (2013). The role of cultural dimensions of international and Dutch students on academic and social integration and academic performance in the Netherlands. International Journal of Intercultural Relations, 37, 188-201.

40. Rienties, B., Luchoomun, D., Tempelaar, D. (2013). Academic and social integration of Master students: A cross-institutional comparison between Dutch and international students. Innovations in Education and Teaching International, 51, 130-141.

41. Sapranaviciute, L., \& Perminas, A. (2012). Stress coping and psychological adaptation in the international students. Central European Journal of medicine, 7(13), 335-343. doi: 2478/s11536-0110161-7.

42. Shkunov, V. N., \& Radchenko, L. R. (2011). The Education of Indian students abroad. Professional Education in Russia and Abroad, 3(11), 6-9.

43. Syzmanowicz , Furnham A. (2011). Gender differences in self-estimates of general, mathematical,spatial and verbal intelligence: Four meta analyses. Learning and Individual Differences, 21, 493-504.

44. Szabo, A., Ward, C., Jose, P. E. (2016). Uprooting stress, coping, and anxiety: A longitudinal study of international students. International Journal of Stress Management, 23 (2), 190-208. https://doi.org/10.1037/a0039771.

45. Vodopyanova, N. Y., \& Starchenkova, E.S. (2009).Sindrom vygoraniya: Diagnostika i profilaktika [Burnout Syndrome: Diagnosis and Prevention]. Petersburg, Russia: Peter.

46. Wang ,J., Hong, J.-Z., Pi, Z.-L. (2015). Cross-cultural adaptation: The impact of online social support and the role of gender. Social Behavior and Personality: An International Journal, 43(1), 111-122.

47. Ward, C. (2001). The A, B, Cs of acculturation. In D. Matsumoto (Ed.). The handbook of culture and psychology. Oxford, England: Oxford University, 411-445.

48. Ward, C., Bochner, S., Furnham, A. (2001). The psychology of culture shock (2nd ed.). Philadelphia: Routledge. 
49. Ward, C., Leung ,C. H. (2015). Chinese sojourners, Chinese hosts: A study of cultural identity and perceived discrimination in international students in Singapore. In Y. Kashima, Y. Endo, E. S. Kashima, C. Leung, \& J. McClure (Vol. Eds.), Progress in Asian social psychology: Vol. 4. Seoul, South Korea: Education Science Publishers, 125-138.

50. Zhang Min, Rask M. (2019). Cross-cultural adaptation and psychometric testing of the Verbal and Social Interaction Questionnaire: A cross-sectional study among nursing students in China. Journal of Clinical Nursing, 28, 2181-2196

51. Zhou, Y., Topping, K., Jindal-Snape D. (2011) Intercultural Adaptation of Chinese Postgraduate Students and their UK Tutors. In: Jin L., Cortazzi M. (eds) Researching Chinese Learners. Palgrave Macmillan, London. https://doi.org/10.1057/9780230299481_11

\section{Supplementary Files}

This is a list of supplementary files associated with this preprint. Click to download.

- Supplementaryinformation.docx 